\title{
Liturgijski temelj zajedništva prezbitera s biskupom
}

\author{
IvICA ŽIŽIIĆ* \\ UDK: 27-524-722.52 • Pregledni članak \\ Primljeno: 8. rujna 2017. • Prihvaćeno: 26. siječnja 2018.
}

${ }^{*}$ Izv. prof. dr. sc. Ivica Žižić, Katolički

bogoslovni fakultet

Sveučilišta u Splitu, Zrinsko-frankopanska 19, 21000 Split, Hrvatska, izizic@kbf-st.hr

Sažetak: Polazeći od zaokreta i rasta u razumijevanju prezbiterata i episkopata na Drugom vatikanskom saboru, autor uvodi u liturgijsko razumijevanje ministerijalnog svećeništva na temelju usporedne analize obrednog slavlja redenja. Prezbiterska i biskupska služba ima se uvijek razumijevati iz njihova služiteljskoga, odnosno zajedničarskoga odnosa jednih $s$ drugima kao is Božjim narodom. Autor obrađuje zadanu temu kroz tri cjeline: otkriće liturgijskog temelja ministerijalnog svećeništva, biskup i svećenik kao eklezijalni subjekti u svjetlu ređenja biskupa i svećenika, prema liturgijskoj teologiji zajedništva: neke naznake za lex vivendi. Kontekstualnom $i$ poredbenom analizom redenja te sosobitim naglaskom na izvornom euhološkom kontekstu, autor zaokružuje razmišljanje iščitavanjem vlastitosti suodnosa svećeničke i biskupske službe čiji je identitet $i$ zajedništvo bogoslužjem Crkve darovano i oblikovano.

Ključne riječi: prezbiter, biskup, obred ređenja, liturgija, teologija zajedništva.

\section{Uvod}

Razmišljanje o liturgijskom temelju zajedništva prezbitera $s$ biskupom ponajprije ima namjeru ukazati na liturgijsko ishodište i temelj prezbiterske i biskupske službe te njihova zajedništva darovanog i oblikovanog liturgijom Crkve. Razvija se kroz tri cjeline. Prva cjelina posvećena je kontekstualnom pitanju liturgijske ekleziologije. U njoj se nalaže ideja liturgije kao sveobuhvatnog temelja koji oblikuje prezbitera i biskupa kao eklezijalne subjekte te se ostvaruje u redu slavljeničke uzajamnosti kako prezbitera među so- 
bom tako i s biskupom is Božjim narodom. Pritom je potrebno barem ukratko ocrtati opće odrednice zaokreta koji se dogodio u poimanju prezbiterata i episkopata, počevši od Drugog vatikanskog sabora (Lumen gentium), a koje su na svoj način proizašle iz obnovljenog razumijevanja bogoslužja kao »vršenja Kristove svećeničke službe $\ll{ }^{1}$

Druga cjelina posvećena je usporednom iščitavanju obreda ređenja prezbitera $i$ biskupa u čijem ću svjetlu pokušati odgovoriti na pitanje zajedničarske naravi biskupa i prezbitera koja im je darovana po sakramentu svetoga reda. Pritom ćemo izdvojiti samo nekoliko elemenata koji nam mogu približiti teologalnu narav tih odnosa. Razlog je tog odabira razumljiv. U liturgiji ređenja, naime, ponajbolje se odražava identitet biskupa i svećenika, te njihova trajna upućenost i uzajamnost darovana po sakramentalnom događaju.

Treća pak cjelina pokušat će pružiti neke naznake za lex vivendi, tj. progovorit će se u kratkim crtama o onim iskustvima i bitnostima koje proviru iz bogoslužja ređenja, a svoj neizostavni kontinuitet pronalaze u redu svećeničkog identiteta i pastoralnoga poslanja.

\section{Otkriće liturgijskog temelja ministerijalnog svećeništva}

Prezbiterima koji, u zajedništvu s biskupima, tvore ministerijalno svećeništvo, povjerena je služba poučavanja, posvećivanja i vođenja zajednice. ${ }^{2}$ Ta trostruka služba, međutim, pronalazi svoje polazište i žarište, kao i svoju realizaciju, u Crkvenom bogoslužju. Krist, utjelovljena Riječ, »glava i pastir « temelj je i biskupske i prezbiterske službe. ${ }^{3}$ Prezbiterska služba pak neodvojiva je od biskupske službe, jer on u njezinu vršenju participira u pastirskoj službi biskupa. ${ }^{4}$ Tijesna povezanost između biskupa i svećenika pronalazi svoj temelj u zajedničkom sudioništvu u Kristovu svećeništvu i liturgijskom životu Crkve. Biskup i svećenici upravo u bogoslužju Crkve stoje najbliže jedni drugima. U liturgiji se, naime, otvara pristup onome što biskup i svećenici jesu, odnosno, otkriva im se zajedničarska narav njihova poslanja te njihova prezbiterskog i biskupskog dostojanstva.

Ove kratke naznake iz bogate liturgijske ekleziologije Drugoga vatikanskog sabora s jedne strane pokazuju obnovljenu svijest Crkve o naravi ministerijalnog svećeniš-

${ }^{1}$ DRUGI VATIKANSKI KONCIL, Sacrosanctum Concilium. Konstitucija o svetoj liturgiji (4. XII. 1963.), br. 7, u: Dokumenti, Zagreb, 1993. (=SC).

${ }^{2}$ DRUGI VATIKANSKI KONCIL, Lumen gentium. Dogmatska konstitucija o Crkvi (21. XI. 1964.), br. 25-27., u: Dokumenti, Zagreb, 1993. (=LG).

${ }^{3}$ Usp. isto, br. 7-8.

${ }^{4}$ Usp. isto, br. 28. 
tva, dok ujedno objavljuju novu liturgijsku paradigmu zajedništva prezbitera s biskupom. Liturgija nanovo postaje perspektiva iz koje se osvjetljava narav, identitet, poslanje, a ponajviše uzajamni odnos koji utemeljuje svećenika i biskupa u slavlju jednog Otajstva (Mysterium) u redu jedne službe (ministerium) u tri stupnja. ${ }^{5}$

Otkriće liturgije, kao »temelja $\ll$ i $\gg$ polazišta $\ll$ za razumijevanje zajedničarske naravi prezbiterske i biskupske službe, zahvaljuje za svoje postojanje nizu povijesno-teoloških razloga, osobito Drugom vatikanskom saboru. Ponajprije, to je plod nadilaženja slike »vojujuće Crkve « (ecclesia militans), dominantne u doba tjeskobnog sučeljavanja Crkve s modernim svijetom. No, i slika mističnog tijela Kristova namjeravala je u stvarnosti potvrditi strogo uzlaznu, hijerarhijsku liniju prema kojoj pitanje zajedništva dolazi u drugi plan. ${ }^{6}$ Saborska liturgijska ekleziologija, usredotočujući se povrh svega na Otajstvo Crkve (ecclesiae mysterium) koja je univerzalni sakrament $\gg$ najtješnjeg sjedinjenja s Bogom i jedinstva cijeloga ljudskog roda ${ }^{7}$, među ostalim, nadišla je i uski svećenički sakralni individualizam koji je još od srednjega vijeka opterećivao bilo svećenika i njegov identitet, bilo njegov odnos s Božjim narodom. ${ }^{8}$ Svećeništvo se jednoć doživljavalo kao »stalež« obavijen nedodirljivom sakralnošću, što znači da je podrazumijevalo određenu »izolaciju « te strogu hijerarhijsku artikuliranost. Taj »sakralni individualizam « dovodio je (a dovodi i dalje) do znatnih poteškoća u razumijevanju i življenju prezbiterata i episkopata kao zajedničarske, ekleziološke stvarnosti.

Sakralizacija biskupa i svećenika nije samo bila odlučujući faktor staleškog razlikovanja od laika, nego i element dubljeg rascjepa na području razumijevanja crkvenih subjekata i njihovih suodnosa. Sakralizacija svećenika i njegovo izdvajanje u svojevrsnu elitnu kastu ujedno je označila žrtvovanje svega onoga što stvarno utemeljuje svećenika i njegovo poslanje, a to je eklezijalni karakter. Naime, u svojoj liturgijskoj funkciji svećenik je viđen kao onaj koji stoji između neba i zemlje, odozgo posredujući milosti svome puku. Svećeništvo se razumije u odnosu na euharistijsku žrtvu, u odnosu prema »moći« (potestas) koju svećenik ima po svetome redu. U

${ }^{5}$ Za cjeloviti pregled teološko-liturgijskog razvoja sakramenta reda vidi: G. CAVAGNOLI, L’Ordine, u: RAZNI AUTORI, Celebrare il Mistero di Cristo. Manuale di Liturgia. Volume II: La Celebrazione dei Sacramenti, Roma, 1996.; G. FERRARO, La liturgia dei sacramenti, Roma, 2008., 271.-399.

${ }^{6}$ A. GRILLO, Comunità dal rito. I presupposti teorici e culturali di una teologia dell'assemblea celebrante, u: G. CAVAGNOLI (ur.), L’Assemblea liturgica, Padova, 2005., 190.-199.

${ }^{7}$ Usp. LG, br. 1.

${ }^{8}$ Lumen gentium u prva dva poglavlja razvija tri temeljne zamisli: prva je u činjenici da se spasenje događa u redu zajedništva koje uspostavlja Božja objava u povijesti, druga je zamisao da Crkva nije isključivo hijerarhijska već i bitno karizmatska i sakramentalna te na koncu da je i pojedina liturgijska zajednica uistinu Crkva. Usp. N. MITCHELL, Ecclesiologia liturgica, u: A. J. CHUPUNGCO, Scientia Liturgica. Manuale di Liturgia. II. Liturgia fondamentale, Casale Monferrato, 1999., 119. 
stvarnosti, svećenik ne pripada zajednici, nego je $\gg \operatorname{iznad} \ll$ nje ili je pak samo njezin predstavnik, ovlašten od Boga i od Crkve, da bude službenik milosti. U svakom pogledu, naglasak se stavlja na izdvajanje koje pruža identitet svećeniku. Izostaju crkveno zajedništvo i odnosi artikulirani u bogoslužju Crkve.

Osim individualističkog poimanja prezbitera, tu je također i individualističko poimanje liturgije. Oni su, naime, uzajamno duboko povezani. Zahvaljujući strogo vertikalnom ekleziološkom modelu u liturgiji nije postojala koncelebracija. Ona je bila rezervirana za samo jedan događaj - svećeničko ređenje - a u svim drugim prilikama drugi su svećenici mogli samo prisustvovati, ne i uzeti udjela u istoj euharistijskoj gesti. Svećenik je dakle određen da bude sam u liturgiji, a ta se činjenica nalaže iz strogo »vertikalnog «, $\gg$ deduktivnog « teološkog razumijevanja prezbiterata i njegove reprezentativne funkcije $u$ odnosu na Boga i na ljude. Ne zaboravimo ni na »privatne mise « bez sudjelovanja puka, koje dodatno govore o određenom autoreferencijalnom modelu svećeništva koji potiskuje zajednicu i zajedništvo kao neku drugotnu stvarnost. ${ }^{9}$ Tradicionalna slika prezbitera, dakle, ovisi o $\gg$ vertikalnom modelu « koji sakralizira osobu službenika i izdvaja ga od drugih u liturgiji i izvan nje, stvarajući oko njega sakralni omotač osame te mu pružajući osjećaj nadmoći nad drugima i izabranja od Boga. Pitanje »odnosa « prema vjernicima, a tako i s biskupom posredovano je i regulirano drugim sredstvima, osobito onim pravnim.

Zaokret na Drugom vatikanskom saboru označio je sljedeće: napuštanje paradigme utemeljene na dvjema ovlastima - potestates koja upućuje na dva paralelna vrela svećeničkog identiteta (sakramentalno ređenje koje ga osposobljava da vrši bogoslužje i crkvena jurisdikcija koja ga osposobljava za navještaj i pastoralnu nadležnost). ${ }^{10}$ Prema tom vertikalnom liturgijsko-pravnom modelu, biskup bi imao »više $\ll$ od svećenika, a ovaj »više « od đakona. Na njihovo mjesto dolazi model tria munera - služba poučavanja, posvećivanja i vođenja zajednice - shvaćena kao trostruka misija na temelju novozavjetnog apostolata. Lumen gentium tom segmentu posvećuje posebnu pozornost. ${ }^{11}$ Teologija tria munera značila je zaokret i ujedno rast. Također

\footnotetext{
${ }^{9}$ Usp. A. ANGENENDT, Liturgia e storia. Lo »sviluppo organico « in questione, Assisi, 2001., 178.189.

${ }^{10} \mathrm{U}$ staroj liturgiji ređenja govorilo se: accipe potestatem offerre sacrificium. Potestas predstavlja ključnu kategoriju prezbiterata, a ređenje se shvaćalo kao čin prenošenja potestates pojedincu. U tom smislu, crkvena je zajednica igrala posve drugotnu ulogu. Ona se pretpostavlja, ali u samoj obrednoj dinamici ređenja nema neku posebnu važnost. Usp. M. KUNZLER, La liturgia della Chiesa, Milano, 2003., 409.-410.

${ }^{11}$ Usp. LG, br. 25-27 za biskupe; usp. isto, br. 28 za svećenike i usp. DRUGI VATIKANSKI KONCIL, Presbyterorum ordinis. Dekret o službi i životu prezbitera (7. XII. 1965.), br. 4-6, u: Dokumenti, Zagreb, 1993. (=PO); usp. LG, br. 29 za đakone.
} 
je riječ o početku novog razumijevanja sakramentalnog temelja svećeništva. Dok je u prijašnjem modelu bogoslužje ulazilo u krug svećenikovih ovlasti koje je primio po ređenju, sada bogoslužje postaje polazištem za njegovu službu te u sebi uključuje odnos prema drugim subjektima, ali i shvaćanje samoga sebe, tj. svojega identiteta iz bogatstva eklezijalnih odnosa. Dolazi, dakle, do premještanja naglaska: od deduktivnog sakraliziranog svećeništva prema prezbiteru kao subjektu u crkvenom zajedništvu s trostrukim poslanjem čiji je prototip i temelj Krist-svećenik. Eklezijalna osnova svećeničke liturgijske službe i njegova identiteta nije dakle nešto što se naknadno pridodaje, nego je ona upravo utemeljujuća. A to se utemeljenje osobito vidi u liturgiji ređenja.

Saborska teologija prezbiterata i episkopata iznova je otkrila eklezijalni odnos kao utemeljujuću kategoriju: biskup u zajedništvu s drugim biskupima i rimskim prvosvećenikom $^{12}$, svećenik u zajedništvu s biskupom i prezbiterima ${ }^{13}$ - sve to govori o odnošajnoj naravi koja bitno, a ne akcidentalno obilježava svećenika i biskupa u njihovu identitetu kako u liturgijskoj službi tako i izvan nje. Osim toga, velike slike Crkve kao Božjeg naroda ${ }^{14}$, Kristova tijela ${ }^{15}$, zaručnice Kristove ${ }^{16}$, sakramenta ${ }^{17}$ sve podjednako uključuju odnos kao životnu formu, odnosno kao konstitutivnu odrednicu Crkve i njezinih raznovrsnih službi. Upravo u tom svjetlu valja promatrati i svećenikov odnos s biskupom u redu bogoslužja Crkve.

\section{Biskup i svećenik kao eklezijalni subjekti u svjetlu ređenja prezbitera i biskupa}

Drugi vatikanski sabor iznova je aktualizirao smisao Crkve, smjestivši pritom ponovno prezbitere i biskupe u red crkvenih odnosa. Biskup i prezbiter ishode iz crkvenog zajedništva, oni su plod Crkve u njezinom životnom odnosu s Kristom Gospodinom, te su ujedno poslani biti predvoditeljima, graditeljima i slaviteljima crkvenog zajedništva. Zajedništvo stoji u začetku i u odredištu njihova zvanja i poslanja. »Sakraliziranje « prezbiterata gotovo je posve apsorbiralo ekleziološki značaj, tj. zajedničarsku narav prezbiterske i biskupske službe. Biskup i svećenik iznova postaju subjekti odnošajno smješteni u okrilje crkvenog zajedništva. To progresivno »smještanje « objavljuje upravo liturgija biskupskog odnosno svećeničkog ređenja.

\footnotetext{
${ }^{12}$ Usp. LG, br. 22-23.

${ }^{13}$ Usp. isto, br. 28.

${ }^{14}$ Usp. isto, br. 9.

${ }^{15}$ Usp. isto, br. 7-8.

${ }^{16}$ Usp. isto, br. 6.

${ }^{17}$ Usp. isto, br. 1.
} 
Naime, u obrednom kontekstu (lex orandi) sa svom se jasnoćom razabire kako zajedničarska narav svećenika i biskupa tako i sakramentalni odnos koji ih utemeljuje i stavlja u suodnos jednih prema drugima, tj. stavlja ih pred njihovo poslanje da oni sami budu nositelji odnosa u Crkvi i u njezinom bogoslužju.

Vlastitost svećeničke i biskupske službe, dakle, ponajbolje se iščitava iz obreda ređenja. Upravo je ređenje životna matrica službe. To je sakramentalna forma gdje $\gg$ nastaje « svećeništvo u pravom smislu te riječi, gdje se ono oblikuje i daruje. Ređenje definira svećenikov i biskupov identitet, oblikuje ga i pruža mu usmjerenje da se dovrši. Zato je neobično važno za svećenike i biskupe pohoditi tu »kolijevku « svoga identiteta i iznova pronaći sebe, preko njega iščitati svoje poslanje i kroz njega prihvatiti svoju crkvenu narav. Ne zaboravimo da misa posvete ulja na Veliki Četvrtak, taj važan trenutak intenzivnog svećeničkog i crkvenog zajedništva, u obrednom programu omogućuje svećenicima da iznova pohode ono slavlje koje ih je oblikovalo kao svećenike te da obnove svoja obećanja u zajedništvu s biskupom i drugim prezbiterima. Nema dvojbe da je obred svećeničkog i biskupskog ređenja toliko teološki složen da ga na ovom mjestu nije moguće detaljno razložiti. ${ }^{18}$ Ipak, pokušat ću iz njega izdvojiti pojedine elemente korisne za cjelovitije razumijevanje naše teme.

Liturgija ređenja biskupa i svećenika u svim svojim dijelovima stavlja u središte prezbiterov odnosno biskupov odnos: odnos prema Kristu, odnos prema Crkvi, odnos prema drugim crkvenim subjektima i odnos prema Božjem narodu u cjelini. Čitav obred ređenja svojevrsno je uvođenje u rečene odnose. Središnji i utemeljujući svakako je odnos s Kristom. Odatle svi odnosi primaju svoj lik i sadržaj. Prezbiter i biskup, mogli bismo reći, izranjaju iz eklezijalnih odnosa i bivaju u njih, svaki na svome stupnju, uvedeni, oblikovani i poslani. ${ }^{19}$ Naime, nitko ne postaje sam od sebe ni svećenik ni biskup. To je služba od drugoga, odnosno, od drugih i Drugoga koji stoji u temelju svih službi i koji je samoga sebe učinio slugom svih - Krista Gospodina, jedinog i velikog svećenika u čijem svećeništvu participiraju kako ministerijalni tako i kraljevski svećenici.

\footnotetext{
${ }^{18}$ Stoga upućujem na vrijedne studije o teologiji ređenja: V. VIOLA, Rinnova in loro l'effusione del tuo Spirito. La spiritualità dei presbiteri a partire dall'ordinazione, Todi, 2010.; S. ESPOSITO, Imita ciò che celebri. Fedeltà di Cristo, fedeltà del sacerdote, Leumann, 2011.

${ }^{19}$ Liturgičar Ante Crnčević razmišlja o tome na sljedeći način: »Prema liturgiji ređenja, identitet prezbitera i njegov duhovni profil uvijek su čitani iz matrice odnosa, ponajprije iz odnosa prema biskupskoj službi kojoj se povjeravaju kao suradnici te, potom, iz odnosa prema Božjemu narodu kojemu su poslani. Pritom valja ne izgubiti iz vida da su i biskupska služba i Božji narod utemeljeni u Kristu. Stoga i njihovi odnosi u Crkvi imaju isti temelj. Prezbiterska duhovnost ne izranja iz njegove vlastite osobnosti ili iz vlastitih duhovnih naklonosti, nego iz 'eklezijalnih odnosa' koji oblikuju bit svećeničkoga poslanja i svećeničke službe.« A. CRNČEVIĆ, Liturgijske slike prezbiterske službe. Teološki naglasci iz liturgije ređenja, u: Diacovensia 18(2010.)2, 279.-290., ovdje 281.
} 
Navedimo bitne elemente iz obreda ređenja koji odražavaju specifičnu teologiju zajedništva.

Pogledamo li strukturu obreda biskupskog ređenja, bit će nam jasno da se ono u svim svojim dijelovima artikulira zajedničarski: ${ }^{20}$

- himan, predstavljanje, čitanje papinskog naloga

Ređenik se ne predstavlja sam pred zajednicu nego uz pratnju dvaju prezbitera. Nakon zaziva Duha himnom O dođi Stvorče jedan od prezbitera pratilaca traži biskupsko ređenje za izabranika nakon čega se čita papinski nalog, a cijela zajednica isti prihvaća usklikom $\gg$ Bogu hvala «. U zajednici se, dakle, predstavlja i prihvaća izabranik.

- nagovor glavnog reditelja

Nagovor također stavlja u središte osnovne elemente biskupskog identiteta i službe, razvijajući bogatu teologiju crkvenog zajedništva s gledišta trostruke službe.

- upit i obećanje izabranika

Pitanja i obećanja još jednom stavljaju pred čitavu zajednicu obveze brige i spremnosti za posvemašnju službu Crkvi (o vršenju službe do smrti, o propovijedanju evanđelja, o čuvanju poklada vjere, o poštivanju kolegijaliteta i vjernosti Petrovu nasljedniku, o očinskoj brizi za svećenike, đakone, siromahe, zabludjele te o spremnosti molitve za svoje stado).

- molitva zajednice (litanije svih svetih)

Zazivom nebeske crkve, zemaljska se ujedinjuje u zagovornoj molitvi za izabranika.

- polaganje ruku i posvetna molitva s polaganjem evanđelistara

Središnji čini biskupskog ređenja - riječju i gestom ukazuju na $\gg$ Duha vodstva $<$ koji se daruje biskupu. Uz biskupa posvetitelja trebaju još biti barem dva biskupa suposvetitelja.

- nadopunjavajući obredi: mazanje glave krizmenim uljem, predaja evandelistara, prstena, mitre, pastirskog štapa, privođenje katedri

Svi nadopunjavajući obredi objavljuju biskupa kao eklezijalni subjekt (svećenik, navjestitelj, zaručnik, učitelj, pastir), kao subjekt odnosa s crkvenom zajednicom.

${ }^{20}$ Strukturu donosimo prema: Rimski pontifikal prerađen odlukom svetog sabora Drugog vatikanskog, objavljen vlašću pape Pavla VI., preuređen brigom pape Ivana Pavla II. Ređenje biskupa, prezbitera $i$ dakona, Zagreb, 2000. (= Rimski pontifikal). (Izvornik: Pontificale Romanum ex decreto Sacrosancti Oecumenici Concilii Vaticani II renovatum, auctoritate Pauli Pp. VI editum, Ioannis Pauli II Pp cura recognitum. De ordinatione Episcopi, presbyterorum et diaconorum, Editio Typica altera, Roma, 1990.) 
- na koncu obreda, nakon popričesne molitve, pjeva se »Tebe Boga hvalimo«, a za to vrijeme novi biskup blagoslivlja puk prolazeći kroz zajednicu.

I taj obredni čin još jednom potvrđuje tijesnu vezu između biskupa i Crkve.

Kao što je vidljivo kako iz cjelovite strukture obrednog programa ređenja tako i iz pojedinih obrednih segmenata, ređenik je unesen u mrežu eklezijalnih odnosa te po njima oblikovan kao eklezijalni subjekt: pastir, učitelj, svećenik Božjeg naroda.

Osnovna struktura obreda ređenja prezbitera veoma je slična. I iz obreda svećeničkog ređenja razabire se ista ekleziološka odrednica. Službu prezbitera treba gledati kao udio u Kristovoj trostrukoj službi koju On nastavlja vršiti u svojoj Crkvi. Prezbitersko ređenje slavi se u okviru nedjeljnog ili blagdanskog euharistijskog slavlja nakon navještaja evanđelja, a ima sljedeću strukturu:

- predstavljanje kandidata $i$ izbor od biskupa

Izbor kandidata nije neovisan o zajednici vjernika koja izražava svoje mišljenje o njihovoj dostojnosti. Zbog toga uvodni dijalog stavlja u središte pozornosti eklezijalni značaj njihova poziva.

\section{- biskupov nagovor}

Biskup koji odabire ujedno naviješta lik prezbitera, a nagovor je izrazito nadahnut učenjem iz Lumen gentium. ${ }^{21}$

- obećanje kandidata sa stavljanjem ruku u biskupove ruke (immixtio manuum)

Kandidati izriču spremnost da preuzmu obveze pastirske, svećeničke i navjestiteljske službe, a potom pojedinac stavlja sklopljene ruke obećavajući » poštovanje i poslušnost «. Ta gesta, koja potječe od starogermanskog običaja prema kojem bi vazal, pri preuzimanju feudalnog dobra u posjed, stavljao svoje ruke u ruke feudalca, sada ima posve drukčije, ekleziološko značenje tijesne uzajamnosti biskupa i svećenika. Svećenik se, naime, povjerava biskupu, a biskup se obvezuje za svoga svećenika. Immixtio manuum vidljivi je pečat njihova jedinstva i uzajamnosti.

- molitva zajednice (litanije svih svetih)

Kao i kod biskupskog ređenja, litanije svih svetih imaju nakanu povezati nebesku i zemaljsku crkvu u poniznoj gesti prostrtosti i u zagovornoj pjesmi za ređenike.

- polaganje ruku i posvetna molitva

Biskup u šutnji polaže ruke na glavu ređenika, a to isto čine i prisutni prezbiteri, koji se potom sabiru oko biskupa sve do kraja posvetne molitve koja slijedi. Polaganje ruku svih prezbitera izražava jedinstvo geste prezbiterija na čelu s biskupom. Svi

${ }^{21}$ Usp. LG, br. 28. 
prezbiteri, naime, budući da su dionici svetoga reda, sudjeluju u sakramentalnom darivanju tog reda. Tako je novi prezbiter takoreći »rođen $\ll$ iz zajedničke sakramentalne biskupove geste u zajedništvu s prezbiterima te posvetne molitve u kojoj se moli da Bog »obnovi u njihovu srcu Duh svetosti $\ll$.

- nadopunjavajući obredi (traditio instrumentorum): oblačenje u misno prezbitersko ruho, pomazanje ruku, predaja kruha i vina

Nadopunjavajući (eksplikativni) obredi iznimno otkrivaju svećenikovu uzajamnost (dostojanstvo, posvetiteljsku službu, odnosno zajedništvo u istoj liturgijskoj službi).

- poljubac mira

Cjelov mira s biskupom (i prezbiterima) konačno pečati prezbiterovo jedinstvo $s$ biskupom, pokazujući svezu ljubavi koji gradi i oblikuje njihovo crkveno zajedništvo.

Zaključno, prezbitersko ređenje na izniman način otkriva otajstvo jedinstva i zajedništva, sakramentalnu svezu između biskupa i svećenika i konačno liturgiju (Mysterium) kao temelj njihove službe (ministerium). Zajedništvo je tu rođeno, oblikovano i ono je predmet trajne izgradnje koja obvezuje kako svećenika tako i biskupa.

\section{Prema liturgijskoj teologiji zajedništva: neke smjernice za lex vivendi}

Liturgija kao mjesto temeljnog odnosa s Kristom i dijaloškog odnosa Crkve u sebi polazište je za teologiju zajedništva prezbitera s biskupom i s čitavim Božjim narodom. Ta nova kultura zajedništva izrasla iz jednoga slavlja Kristova Otajstva počiva na principu slavljeničke uzajamnosti Crkve. U liturgiji se otjelovljuje božansko-ljudski utemeljiteljski odnos koji Crkvu čini Crkvom, a svećenike i biskupe autentičnim službenicima Božjega naroda. Počelo je svega jedinstvo. ${ }^{22}$ Samo polazeći od jedinstva moguće je ispravno razumjeti različitost službi. Jedinstvo Crkve u liturgijskom slavlju počelo je različitosti ministerijalnih službi kao i mjesto gdje se ministerijalno i opće svećeništvo ozbiljuju i ostvaruju.

Drevno načelo legem credendi lex statuat supplicandi (Prosper Akvitanski) govori da je upravo bogoslužje Crkve najintimnije okrilje njezina vjerovanja. ${ }^{23} \mathrm{U}$ njemu se zrcali ono što Crkva vjeruje i ono što ona jest. Otajstvo jedinstva i različitosti Bož-

\footnotetext{
${ }^{22}$ Ono što ujedinjuje onoga tko predsjeda »podijeljenom « liturgijskom zajednicom (jedna vjera, jedan krst, jedno dioništvo u jednom svećeništvu Kristovu) uvijek je veće od onoga što razdvaja ili ih razlikuje. N. MITCHELL, Ecclesiologia liturgica, 123.

${ }^{23}$ Pro Augustino responsiones, PL 51, 209.
} 
jeg naroda, otajstvo njegovih službi i službenika oblikovana su i izražena liturgijom. Po liturgiji Crkva u cjelini i njezini službenici poprimaju specifičan stil, identitet, način življenja i djelovanja koji njihov auctoritas čine uvjerljivim i vjerodostojnim. Ukratko, lex vivendi prezbitera i biskupa proizlazi iz plodnog ispreplitanja lex orandi i lex credendi.

S obzirom na vremensko-prostornu dimenziju bogoslužja ređenja, vrijedi napomenuti da se ređenje slavi u okrilju blagdanske euharistije. Ono je već od samoga početka koncelebracijski artikulirano. Ređenje se slavi u redu slavlja Kristova Otajstva koje dopire do nas i zahvaća nas, te je ono samo dio povijesnih spasenjskih Božjih djela u svome narodu. Pashalno blagdansko iskustvo koje crkvena zajednica živi u nedjeljnom bogoslužju podloga je i pretpostavka za cjelovito slavlje ređenja. ${ }^{24}$ Prostor slavlja ređenja redovito je katedrala, stolna crkva u kojoj se sabire cijela mjesna crkva. Katedrala nije tek izvanjski identitetski simbol, nego mjesto u kojem se crkveno jedinstvo doista oblikuje i daruje. U njoj se, u zajedništvu s biskupom, okuplja crkvena zajednica, tu se ona u pravom smislu ozbiljuje. Ući u katedralu znači ući u zajedništvo vjere. Procesijski hod u obredu ređenja posred zajednice objavljuje ređenike kao dionike Božjeg naroda, a njihovo izabranje prihvaća kao dar zajedništva za zajednicu.

Liturgija odražava intimnu narav Crkve, a Crkva, iako je hijerarhijski strukturirana, ne može se smatrati kleričkom. Biskupi, prezbiteri i đakoni slave bogoslužje u zajedništvu Božjeg naroda, nikako sami za sebe niti sami među sobom. Prava i istinska narav Crkve tijelo je Kristovo u kojem uzimaju udjela svi udovi. U raznolikosti službi odsijeva jedinstvo tog dara i otajstva. Biskupska služba sabire službenike i

\footnotetext{
${ }^{24}$ Liturgičar Vittorio Viola u svom djelcu posvećenom razmišljanju o teologiji ređenja donosi zanimljiva svjedočanstva iz otačkog doba. Tako, primjerice, o tijesnoj svezi između nedjeljne euharistije i ređenja progovara papa Lav Veliki, podsjećajući da je na taj dan nastao svijet, a Krist uskrsnuo te poslao Duha Svetoga. Blagoslov svećeništva povezan je s milosnim darovima u povijesti spasenja. Drugim riječima, vrijeme ređenja i ne može biti drugo nego blagdansko, anamnetsko, liturgijsko koje daje prostora ozbiljenju čudesnih Božjih djela. Drugo je svjedočanstvo osobito zanimljivo. Viola navodi Ordines Romani koji određuju da se ređenje ima slaviti na koncu bdijenja i posta. Ređenje se slavilo u osvit nedjelje. Drugim riječima, ređenje se imalo smjestiti u pashalnu poetiku jutra i njegovih simboličkih aluzija na Uskrsnuće, Uzašašće i poslanje Duha. Usp. V. VIOLA, Rinnova in loro l'effusione del tuo spirito, 15.-17. Današnja crkvena praksa u mnogim biskupijama kod nas, ali i u svijetu, kao da odudara od drevne blagdanske mudrosti Crkve. Ređenja se slave u bezlična subotnja jutra iz »praktičnih « razloga i radi većeg sudjelovanja svećenika koji su nedjeljama »zauzeti«. Funkcionalni razlozi često zastiru snagu obreda, njegova prostora i vremena. U nekim se čak biskupijama običavalo slaviti ređenja po župama, a ne u katedralama, sve s ciljem »buđenja zvanja «. Instrumentalizacija bogoslužja ređenja u druge svrhe zapravo zagušuje izvornu slavljeničku narav ređenja te crkvenoj zajednici u cjelini uskraćuje uistinu bitna iskustva za njezin život i rast.
} 
zajednicu u jedno. Stoga je biskup, prvi liturg Crkve - summa sacri ministeri ${ }^{25}$ - znak tog jedinstva i ujedno pokretač liturgijskog života Crkve. ${ }^{26}$

Liturgijska zajednica kojom predsjeda biskup nije tek jedan trenutak u pastoralnom životu Crkve, nego je organ crkvenog jedinstva u kojem se svi pronalaze i prepoznaju. Zato je neobično važno njegovati zajedničarski stil. On bi trebao odlikovati prezbitera i biskupa u njihovoj međusobnoj upućenosti kao i u upućenosti prema Božjem narodu - liturgijskoj zajednici, nadilazeći sakralni, narcisoidni ili autoritarni stil koji je obilježavao negdašnji autoreferencijalni klerički mentalitet.

Obred ređenja biskupa također stavlja ređenika-izabranika u biskupsku službu u specifičan odnos sa svećenicima. Već u jednom od pitanja od izabranika se traži da prihvati biti »ocem « u zajedništvu sa svojim suradnicima u službi, prezbiterima i đakonima. I u ovoj posvetnoj molitvi ređenika se tumači u odnosu sa starozavjetnim likovima $\gg$ prvaka i svećenika «, počevši od Abrahama, te se traži $\gg$ Duha vodstva « koji je dan ljubljenom Sinu Isusu Kristu, a potom i apostolima. Nadalje, molitva artikulira specifične biskupske službe: služba vrhovnog svećeništva, liturgijska služba, dijeljenje službi kao i svjedočanstvo života na koje je pozvan.

Zanimljivo je da Sacrosanctum Concilium bogoslužje kojemu predsjeda biskup dovodi u precizan odnos s prostorom ( $\gg$ stolna crkva $\ll$, $\gg$ kod jednog oltara $\ll$ ), slavljem ( $\gg$ ista liturgijska slavlja $\ll, ~ \gg$ ista euharistija $\ll, ~ \gg$ ista molitva $\ll$ ) i u raznolikosti službenika i službi (»biskup okružen svećenstvom i služiteljima «). Sve to ukazuje da jedinstvo između biskupa i prezbitera kao i drugih službenika i Božjeg naroda proizlazi iz sakramentalnog djelovanja i u njega se utjelovljuje te zato kvalificira u duhu liturgije. Iz tog duha proizlazi kultura uzajamnosti, suradnje i bliskosti. Nitko ne može tako dobro približiti biskupa svome narodu kao što to može učiniti liturgija. I nigdje svećenici nisu tako blizu biskupu kao u liturgiji, jer tu doista bivaju jedna gesta, jedno tijelo i jedan duh. Euharistijska koncelebracija, koju izričito navodi Lumen gentium kao forma zajedništva prezbitera i biskupa, redoviti je oblik sakramentalne komunikacije tog zajedništva. ${ }^{27}$

${ }^{25}$ Usp. LG, br. 21.

${ }^{26}$ O biskupovoj liturgijskoj naravi progovara Sabor: »Biskup se ima smatrati velikim svećenikom svoga stada; od njega na neki način proistječe i ovisi život vjernika u Kristu. Stoga svi treba da uvelike cijene liturgijski život biskupije, oko biskupa, naročito u stolnoj crkvi. Neka budu uvjereni da se Crkva poglavito očituje u punom i djelatnom učešću svega svetog naroda Božjeg $u$ istim liturgijskim slavljima, a osobito $\mathrm{u}$ istoj euharistiji, $\mathrm{u}$ istoj molitvi, kod jednog oltara kojemu predsjeda biskup okružen svojim svećenstvom i služiteljima « (SC, br. 41).

27 »Premda svećenici nemaju vrhunac pontifikata i u vršenju svoje vlasti ovise o biskupima, ipak su s njima spojeni svećeničkom čašću i posvećuju se po sakramentu reda na sliku Krista (...), da propovijedaju evanđelje, da pasu stado vjernika i da vrše službu Božju, kao pravi svećenici Novoga Zavjeta. Kao dionici službe jedinog posrednika, Krista, u svom stupnju službe navješćuju svima 
Međutim, zajedništvo između biskupa i prezbitera istančano se očituje u gestama svećeničkog ređenja, u onom »neverbalnom « dijelu čije semantičko bogatstvo osobito progovara o otajstvenoj svezi biskupa i svećenika. Izdvojimo samo jedan takav primjer. Takozvani obred immixtio manuum, kojim ređenik obećava biskupu poštovanje i poslušnost, pokazuje snažnu povezanost, štoviše, jedinstvo i uzajamnost koja obvezuje i biskupa i svećenika u njihovu poslanju i upućenosti. Međutim, obredna dinamika na neki način »ponavlja « tu gestu u još nekoliko navrata, iako $s$ različitim varijacijama. Immixtio se, naime, zbiva i kod eksplikativnog obreda predaje plitice s kruhom i kaleža s vinom te kod pomazivanja dlanova uljem krizme. To su oni isti darovi koji će biti prineseni na oltar i u čijoj će se euharistijskoj gesti prvi put ujediniti novozaređeni prezbiter. Euharistija je sveza koja bitno povezuje biskupa i svećenika. Immixtio se, naposljetku, događa i kod poljupca mira. Pružajući ruke jedan drugome i izmjenjujući cjelov mira, biskup i svećenik još jednom potvrđuju svoju uzajamnost utemeljenu na ljubavi.

Polazeći od euhološkog konteksta i kontekstualne obredne hermeneutike, moguće je izdvojiti i neke druge naznake za lex vivendi tj. za razumijevanje identiteta svećenika i biskupa koji su sakramentom združeni u jedan Mysterium i jedan ministerium iako u različitim stupnjevima. ${ }^{28}$ Njihovo jedinstvo ne uklanja različitost, niti različitost onemogućuje jedinstvo. Ministerijalno i misterijsko stoje u nerazrješivoj svezi: slavlje i služba, međutim, opisuju biskupa i svećenika u njihovu identitetu, tj. nalaže se u temelju njihova lex vivendi. Odnos između svećenika i biskupa u svjetlu euholoških tekstova ređenja pobliže nam objašnjava teologalnu narav njihova zajedništva.

Posvetna molitva prezbitera stavlja ređenike u anamnetsko svjetlo biblijskih figura starozavjetnih svećenika i levita te apostola i učenika te u epiklezi traži da Bog u njihovim srcima obnovi $\gg$ duh svetosti $\ll$. O tome naširoko pripovijeda anamnetski dio molitve ređenja u tri dijela. Naime, uz polaganje ruku biskupa i čitavog prezbiterija, kojim se kazuje jedinstvo ministerijalnog svećeništva, te molitvom nad njima, ređenici postaju dionici svećeništva 'drugoga stupnja' (secundi meriti munus). ${ }^{29}$ Riječ je o gestualnoj epiklezi koja se odvija u šutnji, specifičnom pneumatoškom simbolu djelovanja Duha. Odnos između biskupa i svećenika u prvom je redu protumačen odnosom između Mojsija i ‘sedamdesetorice' (usp. Br 11, 16-30), potom Arona i njegovih sinova (usp. Izl 29, 1-37) kao pralik dioništva u istom duhu i sve-

Božju riječ. Svoju svetu službu najviše vrše u euharistijskom bogoslužju ili sinaksi, gdje radeći kao predstavnici Krista proglašuju njegov misterij.« (LG, br. 28.)

${ }^{28}$ Više o euhologiji ređenja: Z. PAŽIN, Prezbiter, navjestitelj i slavitelj Kristova djela spasenja, u: Diacovensia 18(2010.)2, 329.-362.

${ }^{29}$ Rimski Pontifikal, 77. 
ćeništvu. Stoga, posvetna molitva kaže: »Već u Starom savezu razvile su se službe ustanovljene za sveta otajstva: na čelo narodu postavio si Mojsija i Arona da njime vladaju i da ga posvećuju, a druge si muževe odabrao da im pomažu da imadnu udjela u njihovoj službi . $^{30}$

Naposljetku, treća anamneza donosi trinitarnu artikulaciju i kristološki temelj prezbiterata kao i sliku apostola i učenika kao suradnika navjestitelja evanđelja (usp. Lk 10, 1-11 i Lk 9, 1-8) da bi se pokazala dionička, što znači, zajedničarska narav prezbiterata. Vrijedi napomenuti da ove starozavjetne i novozavjetne figure nisu tek 'uzori', nego odnosi po kojima ređenici uzimaju udjela u kontinuitetu trostruke službe. Zajedništvo s biskupima, dakle, bitno obilježava prezbitera u pastirskom, liturgijskom i navjestiteljskom poslanju. Stoga se u epikletskom dijelu molitve ističe:

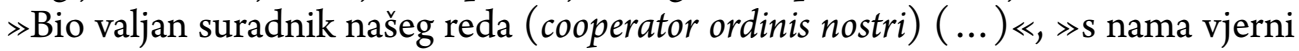
djelitelji otajstava (nobiscum dispensatores fideles mysteriorum) $\ll$, a potom: $\gg$ Neka, Gospodine, s nama bude sjedinjen (nobis iuncti), da bi za narod njemu povjeren $\mathrm{i}$ za cijeli svijet milosrde tvoje molio. ${ }^{31}$ Prezbiteri, biskupovi suradnici, zajedničari istog prezbiterija mjesne Crkve, otajstvo svoga svećeništva žive u sakramentalnom odnosu s biskupom. Svećenik prima samoga sebe po tom odnosu i sebe pronalazi u odnosu suradnje i zajedništva s biskupom u slavljeničkom krilu bogoslužja Crkve.

\section{Zaključak}

Ovih nekoliko odabranih elemenata iz bogoslužja ređenja biskupa i prezbitera, iako ne iscrpljuju svo duhovno i teološko bogatstvo sadržano u bogoslužju ređenja, mogu nam dostatno poslužiti za razumijevanje biskupova i svećenikova odnosa u svjetlu njihove sakramentalne uzajamnosti i darovanosti. Bogoslužje je vrelo i životni kontekst crkvenog zajedništva u cjelini, a ministerijalnog zajedništva zasebno. Biskup i prezbiter služitelji su tog zajedništva i ujedno prvi dionici milosne sveze koju to zajedništvo daruje. Zajedništvo između biskupa i svećenika darovano po liturgiji Crkve priječi pomalo pobožnjačka, stereotipna vrednovanja, koja nerijetko posežu za nadiđenim slikama svećenika kao poluanđeoskog bića, posebnih ovlasti i vrlina. Nostalgični sentimentalizam zapravo nije vodio računa o stvarnosti eklezijalnog identiteta biskupa i svećenika. Svećenik i biskup jesu i djeluju in persona Christi što također znači in persona Ecclesiae. Potrebno je iznova probuditi osjećaj za Božji narod $\mathrm{u} \gg$ koncelebraciji $\ll$ ministerijalnog i općeg svećeništva. ${ }^{32}$ Iz duhovnosti liturgijskog jedinstva, svećenik i biskup mogu sebe otkrivati kao subjekte od-

\footnotetext{
${ }^{30}$ Isto, 76.-77.

${ }^{31}$ Isto.

${ }^{32}$ Usp. C. MILITELLO, Lassemblea liturgica gerarchicamente ordinata: soggetto celebrante, u: G. CAVAGNOLI (ur.), L'Assemblea liturgica, Padova, 2005., 120.
} 
nosa, a ne tek ovlasti ili mističnih moći. Sveti red, naime, osposobljava vjernika da trajno upisuje dar Duha u milost zajedništva Crkve.

Svećenička služba biskupa i prezbitera bitno je eklezijalna stvarnost, a ne osobna, individualna karizma. Stoga, valja je promatrati u svjetlu sakramentalnih odnosa, tj. u duhu dijaloške strukture kršćanskog bogoslužja. Svećenici uzimaju udjela u biskupskoj pastirskoj brizi za Crkvu. Oni su cooperatores ordinis, suradnici onog reda kojega su biskupi nositelji. U tom smislu, oni nose službu drugog reda (secundi meriti munus). Ta stupnjevitost nipošto ne narušava jedinstvo poslanja biskupa i prezbitera, nego neprestano oživljava ordo - sveti red kojemu su po ređenju pridruženi. Zato je biskupska i svećenička služba, proistekla iz istog vrela - Kristova svećeništva i svećeništva njegove Crkve, dio istog univerzalnog poslanja: $\gg$ da svi narodi, sabrani u Kristu, postanu jednim Božjim narodom i potpuno se ostvare $u$ njegovu Kraljevstvu $\ll .33$

${ }^{33}$ Rimski Pontifikal, 77. 


\title{
THE LITURGICAL FOUNDATION OF THE COMMUNION OF PRESBYTERS WITH THE BISHOP
}

\author{
Ivica ŽIIŽIĆ*
}

Summary: Starting from the change and development in the understanding of the presbyterate and the episcopate at the Second Vatican Council, the author introduces the liturgical understanding of ministerial priesthood based on a comparative analysis of the ceremonial rite for the ordination of priests. The ministry of presbyters and bishops must always be understood from their ministerial, that is, their communal relationship with one another as well as with God's people. The author develops the given topic in three units: the discovery of the liturgical foundation of ministerial priesthood; the bishop and priest as ecclesial subjects in the light of the ordination of bishops and priests; according to the liturgical theology of communion: some indications for lex vivendi. Through the contextual and comparative analysis of ordination and with a special emphasis on the original euchological context, the author concludes the reflection by reading the distinctiveness of the correlation of priestly and bishop's ministry, whose identity and communion is given and formed by the worship of the Church.

Keywords: presbyter, bishop, the rite of ordination, liturgy, the theology of communion.

* Assoc. Prof. Ivica Žižić, Catholic Faculty of Theology, University of Split, Zrinsko-frankopanska 19, 21000 Split, Croatia, izizic@kbf-st.hr 